\title{
KEMAMPUAN PEMECAHAN MASALAH FISIKA PESERTA DIDIK MELALUI MODEL PEMBELAJARAN INKUIRI TERBIMBING BERBANTUAN POST ORGANIZER
}

\author{
Arini Rizqa ${ }^{1)}$, Ahmad Harjono1), Wahyudi') \\ 1)Program Studi Pendidikan Fisika, FKIP, Universitas Mataram, Mataram, NTB, Indonesia \\ Corresponding author : Arini Rizqa \\ E-mail : arini.rizqa@gmail.com
}

Diterima 06 Oktober 2020, Direvisi 04 November 2020, Disetujui 04 November 2020

\begin{abstract}
ABSTRAK
Pendidikan bertujuan mendidik individu yang dapat menyelesaikan masalah dalam kehidupan seharihari. Kemampuan pemecahan masalah dapat dilatih dengan membiasakan peserta didik menyelesaikan sebanyak mungkin masalah melalui penerapan model pembelajaran yang tepat di kelas. Penelitian ini dirancang untuk mengintegrasikan model pembelajaran inkuiri terbimbing dengan bantuan post organizer dalam rangka meningkatkan kemampuan pemecahan masalah fisika peserta didik. Tujuan penelitian ini untuk mengetahui pengaruh model pembelajaran inkuiri terbimbing berbantuan post organizer terhadap kemampuan pemecahan masalah fisika peserta didik. Jenis penelitian ini adalah eksperimen semu dengan non-equivalent control group design. Penelitian ini dilaksanakan di SMAN 1 Gerung dengan populasi seluruh peserta didik kelas XI MIPA tahun ajaran 2019/2020. Teknik pengambilan sampel menggunakan teknik purposive sampling yaitu kelas XI MIPA 4 sebagai kelas eksperimen dan XI MIPA 7 sebagai kelas kontrol. Indikator pemecahan masalah yang dinilai adalah useful description, specific application of physics, dan mathematical procedures. Uji hipotesis menggunakan uji-t dua pihak dengan rumus $t$-test polled varians pada taraf signifikansi $5 \%$. Simpulan penelitian ini adalah terdapat pengaruh model pembelajaran inkuiri terbimbing berbantuan post organizer terhadap kemampuan pemecahan masalah fisika peserta didik.
\end{abstract}

Kata kunci: inkuiri terbimbing; post organizer; kemampuan pemecahan masalah fisika.

\begin{abstract}
Education aims to educate individuals who can solve problems in daily life. Problem solving skills can be trained by getting students to settle as many problems as possible through the application of appropriate learning models in the classroom. This research was designed to integrate the guided inquiry learning model with a post organizer in order to improve students' physics problem solving skills. The purpose of this research was to determine the effect of guided inquiry learning model assisted by the post organizer on students' physics problem solving skills. This research used quasi-experimental with non-equivalent control group design. This research was conducted at SMAN 1 Gerung with a population of all students of class XI MIPA in the academic year 2019/2020. The sampling technique uses purposive sampling technique, namely class XI MIPA 4 as an experimental class and XI MIPA 7 as a control class. Indicators of problem solving assessed were useful description, specific application of physics, and mathematical procedures. Hypothesis testing used two-party t-test with the formula of ttest polled variance at a significance level of $5 \%$. The conclusion of this research indicatd that there was an influence of the guided inquiry learning model assisted by the post organizer on the students' physics problem-solving skills.
\end{abstract}

Keywords: guided inquiry; post organizer; physics problem-solving skills.

\section{PENDAHULUAN}

Pendidikan modern bertujuan mendidik individu yang dapat menyelesaikan masalah dalam kehidupan (Selçuk et al., 2008). Pendidikan di sekolah menekankan pada pengembangan kecakapan hidup (life skill) peserta didik agar siap memecahkan masalah yang dihadapi dalam kehidupan sehari-hari
(Simbolon \& Sahyar, 2015). Kemampuan pemecahan masalah adalah kecakapan menerapkan pengetahuan yang diperoleh sebelumnya ke dalam situasi yang belum dikenal (Hertiavi et al., 2010). Hoy dan Margetts (Hoy \& Margetts, 2013) mendefinisikan kemampuan pemecahan masalah sebagai perumusan jawaban baru melebihi penerapan 
sederhana dari aturan yang dipelajari sebelumnya untuk menciptakan solusi.

Kemampuan pemecahan masalah adalah hal fundamental yang harus dimiliki peserta didik. Pemecahan masalah merupakan aktivitas intelektual yang sangat penting dalam ilmu sains (Heller \& Reif, 1984). Pendidikan sekolah bertujuan mengajar peserta didik untuk menyelesaikan berbagai masalah termasuk masalah fisika. Jewett dan Serway (Jewett \& Serway, 2008) menyatakan bahwa kemampuan pemecahan masalah merupakan salah satu ujian utama pengetahuan fisika dan menyarankan untuk memecahkan masalah sebanyak mungkin.

Kemampuan pemecahan masalah fisika peserta didik SMAN 1 Gerung tergolong rendah. Larkin dan Reif (Larkin \& Reif, 1979) menyatakan bahwa kemampuan pemecahan masalah yang rendah ditandai dengan kesulitan yang dihadapi peserta didik dalam mengaplikasikan pengetahuannya untuk menyelesaikan suatu permasalahan fisika. Hasil wawancara dengan seorang guru mata pelajaran fisika di SMAN 1 Gerung menunjukkan bahwa hal tersebut karena peserta didik mengalami kesulitan dalam 1) memahami maksud soal, 2) menyatakan informasi soal ke dalam bentuk simbol-simbol fisika, 3) operasi matematika. Penyebab lain juga muncul dari guru yaitu: 1) guru tidak menerapkan model pembelajaran yang dapat melatih kemampuan pemecahan masalah peserta didik. Guru mendominasi pembelajaran (teacher centered) dengan lebih banyak menyajikan informasi/materi. Pembelajaran yang diterapkan kurang mencerminkan karakteristik mata pelajaran fisika sebagai sebagai proses. Muammar et al (Muammar et al., 2015) menyatakan bahwa fisika sebagai proses berarti pemahaman mengenai bagaimana informasi ilmiah fisika dapat diperoleh dengan melakukan pengamatan, pengukuran, penyelidikan dan publikasi. 2) guru jarang memanfaatkan pengetahuan yang telah dimiliki peserta didik untuk menghadirkan pembelajaran bermakna. Pemecahan masalah adalah keterampilan kompleks. Guru berperan penting dalam melatih kemampuan pemecahan masalah peserta didik melalui penerapan model pembelajaran yang tepat di kelas.

Salah satu model pembelajaran yang dapat melatih kemampuan pemecahan masalah peserta didik adalah model pembelajaran inkuiri. Model pembelajaran inkuiri adalah model pembelajaran yang bersifat student centered dalam rangka menemukan dan menyelidiki konsep melalui kegiatan eksperimen untuk mencari solusi dari masalah yang diberikan (Simbolon \& Sahyar, 2015).
Pembelajaran inkuiri memiliki beberapa tingkatan yaitu inkuiri terkontrol, inkuiri terbimbing, inkuiri terencana, dan inkuiri bebas (Anam, 2015). Inkuiri terkontrol memberikan kesempatan kepada guru untuk menentukan topik atau materi pelajaran dengan tetap mengikuti instruksi guru. Inkuiri terbimbing membolehkan peserta didik dalam menentukan gaya belajar, namun tetap sesuai dengan bimbingan guru. Peserta didik terlibat aktif dalam seluruh proses pembelajaran, mulai dari pemilihan tema/topik, proses belajar, hingga model penugasan pada penerapan inkuiri terkontrol. Inkuiri bebas memberikan kesempatan kepada peserta didik belajar secara mandiri, membangun masalah dan memecahkan masalah tersebut dengan usaha mereka sendiri. Penelitian ini menggunakan model inkuiri terbimbing. Hal ini sesuai dengan kondisi peserta didik yang masih memerlukan bimbingan untuk memulai belajar mandiri. Hal serupa dinyatakan Gormally et al (Gormally et al., 2011) bahwa inkuiri terbimbing menyediakan lebih banyak arahan bagi peserta didik yang belum siap menyelesaikan masalah dengan inkuiri tanpa bantuan akibat kurangnya pengalaman dan pengetahuan. Model pembelajaran inkuri terbimbing adalah model pembelajaran yang menitikberatkan aktivitas peserta didik dalam memecahkan masalah. Model ini bersifat student centered dengan guru sebagai fasilitator pembelajaran dalam rangka menyelidiki dan menemukan sendiri solusi dari masalah yang diberikan guru. Penelitian terkait pengaruh model pembelajaran inkuiri terbimbing telah banyak dilakukan. Model pembelajaran inkuiri terbimbing berpengaruh terhadap kemampuan berpikir logis peserta didik (Purwanto, 2012). Pembelajaran inkuiri terbimbing memberikan pengaruh yang signifikan terhadap keterampilan proses sains dasar peserta didik (Ambarsari, 2012).

Penerapan model pembelajaran di kelas tidak terbatas pada penggunaan satu model saja. Guru dapat mengkombinasikan model pembelajaran dalam rangka mengoptimalkan pembelajaran. Pengoptimalan tersebut dapat dilakukan dengan menghadirkan pembelajaran bermakna bagi peserta didik. Pengetahuan yang dipelajari akan bermakna jika dikaitkan dengan pengetahuan yang telah dimiliki peserta didik sebelumnya. Model pembelajaran inkuiri terbimbing dalam penelitian ini akan dikombinasikan dengan sebuah pengait/bantuan yang disebut post organizer (PO). PO adalah informasi penghubung antara materi baru yang dipelajari peserta didik dengan pengetahuan yang telah dimiliki dan disajikan setelah pembelajaran (Oktaviani et al., 2018). PO secara positif 
memengaruhi daya ingat peserta didik terhadap konten pembelajaran (Chung \& Cheon, 2010). Bantuan $P O$ diharapkan dapat mengoptimalkan pembelajaran dalam rangka meningkatkan kemampuan pemecahan masalah fisika peserta didik. Penelitian Oktaviani et al (Oktaviani et al., 2018) menunjukkan bahwa $P O$ mengarahkan peserta didik untuk menyimpulkan materi dan menolong mereka dalam mengaitkannya dengan pengetahuan yang telah dimiliki sehingga dapat membantu menanamkan pengetahuan baru dalam diri mereka. Romberg dan Wilson (Romberg \& Wilson, 1973) menemukan bahwa $P O$ bermanfaat dalam meningkatkan kemampuan daya ingat. Bernard (Bernard, 1977) menyatakan bahwa $P O$ efektif dalam membantu proses retensi materi baru.

Model pembelajaran inkuiri terbimbing dengan bantuan $P O$ diduga merupakan kombinasi yang tepat dalam mengoptimalkan proses belajar peserta didik. Kombinasi ini diharapkan dapat meningkatkan kemampuan pemecahan masalah fisika peserta didik. Penelitian tentang pengaruh model pembelajaran inkuiri terbimbing berbantuan $P O$ terhadap kemampuan pemecahan masalah fisika peserta didik belum pernah dilakukan. Hasil penelitian ini diharapkan dapat menjadi informasi tambahan bagi guru dalam mengelola pembelajaran untuk meningkatkan kualitas pendidikan.

\section{METODE PENELITIAN}

Penelitian ini menggunakan rancangan eksperimen semu dengan non-equivalent control group design. Penelitian ini dilaksanakan di SMAN 1 Gerung dengan populasi semua peserta didik kelas XI MIPA tahun ajaran 2019/2020. Pengambilan sampel menggunakan teknik purposive sampling. Kelas XI MIPA 4 sebagai kelas eksperimen dengan sampel sebanyak 24 orang dan kelas XI MIPA 7 sebagai kelas kontrol dengan sampel berjumlah 29 orang.

Penelitian ini menggunakan instrumen tes berupa soal uraian sebanyak 6 soal. Penelitian dilakukan dengan mengambil dua data dari masing-masing kelompok sampel. Pengambilan data pre-test dilakukan sebelum perlakuan dan data post-test setelah perlakuan. Perlakuan yang dimaskud berupa model pembelajaran inkuiri terbimbing berbantuan $P O$ pada kelas eksperimen dan model pembelajaran konvensional pada kelas kontrol. Data pre-test dan post-test selanjutnya diuji normalitas dan homogenitasnya. Uji hipotesis menggunakan uji-t dua pihak dengan rumus $t$ test polled varians pada taraf signifikansi $5 \%$.

\section{HASIL DAN PEMBAHASAN}

Hasil penelitian ini memperlihatkan bahwa terdapat pengaruh model pembelajaran inkuiri terbimbing berbantuan post organizer (PO) terhadap kemampuan pemecahan masalah fisika peserta didik. Hal ini terlihat dari persentase kemampuan pemecahan masalah kelas eksperimen yang diberi perlakuan berupa model pembelajaran inkuiri terbimbing berbantuan $P O$ lebih tinggi daripada kelas kontrol yang diberi perlakuan berupa model pembelajaran konvensional. Hasil ini terjadi karena: 1) model pembelajaran inkuiri terbimbing melatih kemampuan pemecahan masalah fisika peserta didik. Model ini memberikan arahan yang jelas kepada peserta didik dalam memecahkan masalah yang diberikan guru melalui prosedur menjawab pertanyaan/masalah, membuat hipotesis, melakukan percobaan, mengolah dan menganalisis data, serta membuat simpulan. Hal ini sejalan dengan teori Piaget yang menyatakan bahwa pengetahuan tidak bisa begitu saja ditransfer, tetapi harus dibangun dan ditafsirkan oleh peserta didik melalui pengalaman (Suparno, 1997). Muammar et al (Muammar et al., 2015) juga menyatakan bahwa salah satu karakteristik mata pelajaran fisika adalah fisika sebagai proses yang berarti pemahaman mengenai bagaimana informasi ilmiah fisika dapat diperoleh dengan melakukan pengamatan, pengukuran, penyelidikan, dan publikasi. Hasil ini diperkuat oleh penelitian Simbolon dan Sahyar (Simbolon \& Sahyar, 2015), Yeritia et al (Yeritia et al., 2017), Novianty et al (Novianty et al., 2013), dan penelitian lainnya yang menunjukkan bahwa model pembelajaran inkuiri terbimbing memfasilitasi penguasaan konsep, aktivitas, kemampuan pemecahan masalah, dan hasil belajar peserta didik. 2) $P O$ menghadirkan pemelajaran bermakna bagi peserta didik. Pembelajaran bermakna berperan dalam memperkuat struktur kognitif peserta didik sehingga informasi/pengetahuan yang diterima peserta didik menjadi tahan lama. Hal ini sejalan dengan teori Ausubel (Ausubel, 2000) yang menyatakan bahwa meaningful learning terjadi apabila informasi-informasi baru yang dipelajari diasimilasikan ke dalam struktur kognitif peserta didik. Ausubel dan Novak menyatakan bahwa kelebihan meaningful learning antara lain: informasi yang dipelajari secara bermakna dapat diingat lebih lama, informasi baru yang dikaitkan dengan konsepkonsep relevan yang dimiliki dapat memperkuat keberadaan konsep-konsep tersebut sehingga memudahkan pembelajaran berikutnya dengan materi yang mirip, dan informasi yang dilupakan setelah pernah dikuasai sebelumnya masih 
meninggalkan bekas sehingga memudahkan penerimaan informasi baru yang memiliki kemiripan dengannya (Yuniati, 2013). Hasil ini diperkuat oleh penelitian Oktaviani et al (Oktaviani et al., 2018), Bernard (Bernard, 1977), Harrington (1968) dan Bauman et al (1968) (dalam (Peterson et al., 1973)), serta Bauman dan Glass (1970) (dalam (Wong, 1972)) yang menemukan bahwa $P O$ dapat memfasilitasi meaningful learning.

Penyajian $P O$ berbentuk peta konsep memudahkan peserta didik dalam memahami keterkaitan/hubungan antar konsep. Peta konsep adalah alat untuk merepresentasikan hubungan antar konsep secara sederhana dan berurutan. Novak et al (Novak et al., 1984) menganjurkan pemahaman konsep-konsep kunci dan hubungan antar konsep yang dinilai penting. Ausubel menyatakan bahwa peta konsep menjanjikan untuk menjadi berguna dalam meningkatkan meaningful learning dan pemahaman konseptual peserta didik dalam sains dan fisika. Berdasarkan teori asimilasi, peta konsep memfasilitasi meaningful learning (sebagai lawan rote learning) dengan membuat hubungan konseptual yang eksplisit (Sinambela, 1997).

Indikator pemecahan masalah (IPM) yang dinilai dalam penelitian ini diadaptasi dari IPM Docktor dan Heller (Docktor \& Heller, 2009) yaitu useful description (IPM-1), specific application of physics (IPM-2), dan mathematical procedures (IPM-3). Kemampuan pemecahan masalah kelas eksperimen pada ketiga indikator ini lebih unggul daripada kelas kontrol. Rata-rata nilai post-test kemampuan pemecahan masalah fisika kelas eksperimen dan kelas kontrol pada tiap IPM dapat dilihat pada Gambar 1.

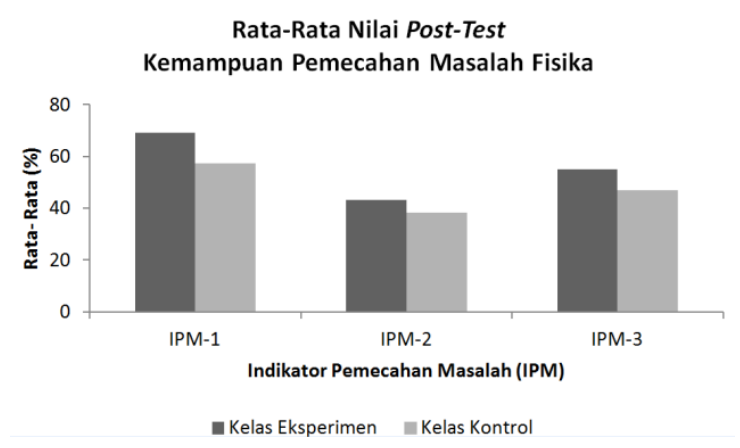

Gambar 1. Rata-Rata Nilai Post-Test Kemampuan Pemecahan Masalah Fisika

Temuan penelitian ini menunjukkan bahwa model pembelajaran inkuiri terbimbing berbantuan $P O$ berpengaruh terhadap kemampuan pemecahan masalah fisika peserta didik. Kelebihan kombinasi model pembelajaran inkuiri terbimbing dengan bantuan $P O$ dalam bentuk peta konsep adalah kombinasi ini melatih kemampuan pemecahan masalah fisika peserta didik, memfasilitasi peserta didik dalam menemukan/membangun konsep fisika dalam dirinya, dan keberadaan konsep tersebut semakin diperkuat dan tahan lama dengan pemberian $P O$ di akhir pembelajaran.

\section{SIMPULAN DAN SARAN}

Berdasarkan hasil pengujian hipotesis penelitian dan pembahasan dapat disimpulkan bahwa terdapat pengaruh model pembelajaran inkuiri terbimbing berbantuan post organizer terhadap kemampuan pemecahan masalah fisika peserta didik. Model pembelajaran inkuiri terbimbing berperan dalam melatih kemampuan pemecahan masalah fisika peserta didik. Pemberian post organizer berperan dalam menghadirkan pembelajaran bermakna dan memperkuat struktur kognitif bagi peserta didik sehingga informasi/pengetahuan yang diterima peserta didik dapat tahan lama.

Saran-saran yang diajukan antara lain: 1) seyogyanya guru mengatur alokasi waktu sebaik mungkin dalam menerapkan model pembelajaran inkuiri terbimbing pada peserta didik yang baru memulai belajar mandiri. 2) post organizer seyogyanya sesuai dengan materi fisika dan pengetah dan pengetahuan yang telah ada dalam struktur kognitif peserta didik.

\section{DAFTAR RUJUKAN}

Ambarsari, W. (2012). Penerapan Pembelajaran Inkuiri Terbimbing terhadap Keterampilan Proses Sains Dasar pada Pelajaran Biologi Siswa Kelas VIII SMP Negeri 7 Surakarta.

Anam, K. (2015). Pembelajaran Berbasis Inkuiri: Metode dan Aplikasi. In Yogyakarta: Pustaka Pelajar.

Ausubel, D. P. (2000). The Acquisition and Retention of Knowledge: A Cognitive View. Springer Science \& Business Media.

Bernard, M. E. (1977). The Effects of Advance Organizer, Sequence of Instruction, and Post Organizer on the Learning and Retention of a Taxonomy of Concepts. Australian Journal of Education, 21(1), 25-33.

Chung, S., \& Cheon, J. (2010). The Effects of Post Organizers in Game-Based Learning. Texas Tech University, 23(4), 17-20.

Docktor, J., \& Heller, K. (2009). Robust Assessment Instrument for Student Problem Solving. Proceedings of the NARST 2009 Annual Meeting, Garden 
Grove, CA, 1-19.

Gormally, C., Brickman, P., Hallar, B., \& Armstrong, N. (2011). Lessons Learned About Implementing an Inquiry-Based Curriculum in a College Biology Laboratory Classroom. Journal of College Science Teaching, 40(3), 45-52.

Heller, J. I., \& Reif, F. (1984). Prescribing Effective Human Problem-Solving Processes: Problem Description in Physics. Cognition and Instruction, 1(2), 177-216.

Hertiavi, M. A., Langlang, H., \& Khanafiyah, S. (2010). Penerapan Model Pembelajaran Kooperatif Tipe Jigsaw untuk Peningkatan Kemampuan Pemecahan Masalah Siswa SMP. Jurnal Pendidikan Fisika Indonesia, 6, 53-57.

Hoy, A. W., \& Margetts, K. (2013). Educational Psychology (3rd ed.). Pearson Australia.

Jewett, J. W., \& Serway, R. A. (2008). Physics for Scientists and Engineers with Modern Physics (7th ed.). Thomson Learning.

Larkin, J. H., \& Reif, F. (1979). Understanding and Teaching Problem-Solving in Physics. European Journal of Science Education, 1(2), 191-203.

Muammar, H., Harjono, A., \& Gunawan. (2015). Pengaruh Model Pembelajaran Assure dan Pengetahuan Awal Terhadap Hasil Belajar IPA-Fisika Siswa Kelas VIII SMPN 22 Mataram. Jurnal Pendidikan Fisika Dan Teknologi, 1(3), 166-172.

Novak, J. D., Gowin, D. B., \& Bob, G. D. (1984). Learning How to Learn. Cambridge University Press.

Novianty, I., Sulistina, O., \& Zakia, N. (2013). Efektivitas Penerapan Modul Materi Analisis Elektrokimia Berbasis Inkuiri Terbimbing Terhadap Hasil Belajar dan Persepsi Siswa Kelas Xi Semester 1 Kompetensi Keahlian Kimia Analisis Smkn 7 Malang. Universitas Negeri Malang: Jurnal-Online. Um. Ac. Id.

Oktaviani, D. G., Harjono, A., \& Gunada, I. W. (2018). Penguasaan Konsep Usaha Dan Energi Peserta Didik Kelas X Dengan Model Pembelajaran Ekspositori Berbantuan Organizers. Jurnal Pendidikan Fisika Dan Teknologi, 4(2), 192-201.

Peterson, J. C., Thomas, H. L., Lovett, C. J., \& Bright, G. W. (1973). The Effect of Organizers and Knowledge of Behavioral Objectives on Learning a Mathematical Concept. Journal for Research in Mathematics Education, 4(2), 76-84.

Purwanto, A. (2012). Kemampuan Berpikir Logis Siswa SMA Negeri 8 Kota Bengkulu dengan Menerapkan Model Inkuiri
Terbimbing dalam Pembelajaran Fisika. Jurnal Exacta, 10(2), 133-135.

Romberg, T. A., \& Wilson, J. W. (1973). The Effect of an Advance Organizer, Cognitive Set, and Post Organizer on the Learning and Retention of Written Materials. Journal for Research in Mathematics Education, 4(2), 68-76.

Selçuk, G. S., Çalýskan, S., \& Erol, M. (2008). The Effects of Problem Solving Instruction on Physics Achievement, Problem Solving Performance and Strategy Use. LatinAmerican Journal of Physics Education, 2(3), 151-166.

Simbolon, D. H., \& Sahyar. (2015). Pengaruh Model Pembelajaran Inkuiri Terbimbing Berbasis Eksperimen Riil dan Laboratorium Virtual terhadap Hasil Belajar Fisika Siswa. Jurnal Pendidikan Dan Kebudayaan, 21(3), 299-315.

Sinambela, I. T. (1997). Tes Esai Pemetaan Konsep sebagai Alat Ukur dalam Belajar Bermakna. Jurnal Ilmu Pendidikan, 4(1).

Suparno, P. (1997). Filsafat Konstruktivisme dalam Pendidikan. In Yogyakarta: Kanisius.

Wong, M. R. (1972). Annual Meeting of the American Educational Research Assn. Additive Effects of Advance Organizers, $1-13$.

Yeritia, S., Wahyudi, W., \& Rahayu, S. (2017). Pengaruh Model Pembelajaran Inkuiri Terbimbing terhadap Penguasaan Konsep dan Kemampuan Berpikir Kritis Fisika Peserta Didik Kelas X SMAN 1 Kuripan Tahun Ajaran 2017/2018. Jurnal Pendidikan Fisika Dan Teknologi, 3(2), 181-187.

Yuniati, S. (2013). Peta Konsep (Mind Mapping) dalam Pembelajaran Struktur Aljabar. Gamatika, 3(2), 129-139. 